\title{
Simple and Rapid Method for Identification of Curcuma Longa Rhizomes by Physicochemical and HPTLC Fingerprint Analysis
}

\author{
S. C. VERMA ${ }^{a^{*}}$, C. L. JAIN ${ }^{b}$, R. RANI ${ }^{\mathrm{a}}$, P. PANT ${ }^{\mathrm{a}}$, R. SINGH ${ }^{\mathrm{a}}$, \\ M. M. PADHI ${ }^{a}$ and R. B. DEVALLA ${ }^{a}$
}

${ }^{\mathrm{a} C e n t r a l ~ C o u n c i l ~ f o r ~ R e s e a r c h ~ i n ~ A y u r v e d i c ~ S c i e n c e s, ~ 61-65, ~ I n s t i t u t i o n a l ~ A r e a, ~}$ Opp.-D-Block, Janakpuri, New delhi-110058, India

${ }^{\mathrm{b}}$ Ex-H.O.D, Department of Chemistry, M. M. H. College, Ghaziabad, U.P., India

scvpharma@gmail.com

Received 24 May 2012 / Accepted 13 June 2012

\begin{abstract}
Curcuma longa L. rhizomes are widely used by the traditional medical practitioners for curing various diseases. The rhizomes of $C$. longa $\mathrm{L}$. is commonly known as Haldi or Turmeric. Haldi is of special importance to human with the discovery that its rhizome powder, when added to various food preparations, preserves their freshness and imparts a characteristic flavors. The Indian system of medicine comprises of Ayurveda, Siddha and Unani. In these systems many medicine are made up of C. longa rhizomes. In Ayurveda, turmeric has been used internally as a stomachic, tonic, blood purifier and externally in the prevention and treatment of skin diseases. The World Health Organization (WHO) in 1999 had given a detail protocol for quality contol of single herbal drugs, but very little literature is available for detailed standardization of single plant drugs. We have developed simple and rapid identification method for authentication of $C$. longa rhizome. Physicochemical parameters and HPTLC fingerprint analysis of $C$. longa rhizomes were also carried out. The drug was also extracted with solvent of increasing polarities like $n$-hexane, dichloromethane, ethyl acetate, acetone, absolute ethanol and commercial ethanol (80\%) for extraction of curcuminoids. The results indicated that ethyl acetate and acetone were most suitable solvent for maximum extraction of curcuminoids from C. longa rhizomes. The study revealed different analytical parameters of the crude drug which will be useful in identification of genuine drug and control of adulterations.
\end{abstract}

Keywords: Curcuma longa L. Rhizomes, Physicochemical parameters, HPTLC fingerprint analysis

\section{Introduction}

Curcuma longa L. (Family Zingiberaceae) is a perennial herb as shown in Figure 1. Plant is a native of South Asia and is cultivated throughout warmer parts of the world. It is extensively cultivated in all parts of India. The crop is harvested after 9-10 months when 
lower leaves turn yellow rhizomes carefully dug up with hand-picks between October-April and cured by boiling and dried ${ }^{1}$. Morphologically, it is a perennial, rhizomatous herbs or under shrubs, up to $1 \mathrm{~m}$. tall; rhizomes much branched (Figure 2), bright-yellow to orange, cylindric, aromatic; leaves petiolate; petioles $20-45 \mathrm{~cm}$ long; lamina green, oblonglanceolate or elliptic, 30-45 x 15-18 cm, glabrous, shortly acuminate at apex; inflorescence spicate, terminal on pseudostems; peduncles $12-20 \mathrm{~cm}$ long; spikes cylindric, densely many flowered; fertile bracts pale-green, ovate-oblong, obtuse; coma bracts spreading, white, mixed with green, acute; flowers white to pale-yellow, sometimes tinged with reddishpurple, with a yellow band at the centre; ovary sparsely hairy ${ }^{2}$. Transverse section of rhizome shows epidermis with thick-walled cubical cells of various dimensions; a few layers of cork developed under epidermis and scattered oleo-resin cells with brownish contents; cork generally composed of 4-6 layers of thin-walled, brick shaped parenchyma; cortex characterized by the presence of mostly thin walled, rounded parenchyma cells; scattered collateral vascular bundles, vessels mainly spirally thickened, a few reticulate and annular; cells of ground tissue and cortex contain starch grains of 4-15 $\mu \mathrm{m}$ in diameter. Oil cell with subrised walls containing orange-yellow globules of volatile oil or amorphous resinous matter, vessels mainly spirally thickened, a few recticulate and annular ${ }^{3}$.

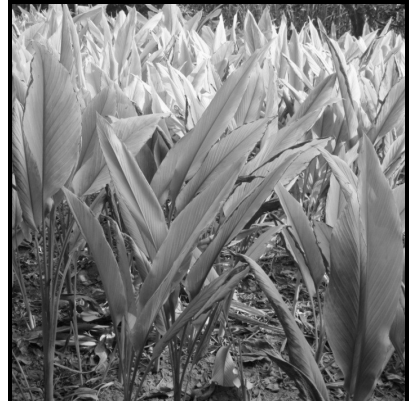

Figure 1. Curcuma longa L. Plant

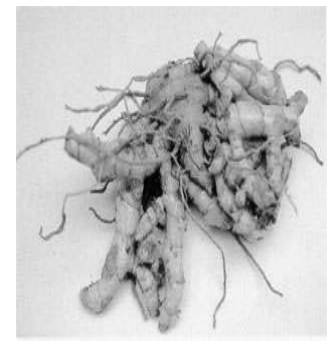

Figure 2. C. longa Rhizome

In recent years, there has been an increasing demand of $C$. longa $\mathrm{L}$. rhizomes due to growing preference by consumers for high quality dietary spice and coloring agents for food, cosmetics and textiles that are deemed to be natural with minimal chemical exposure ${ }^{4-5}$. The powder of rhizomes of $C$. longa is commonly known as Turmeric powder or Haldi. The main colored substances in the rhizomes are curcuminoids; it is a main combination of curcumin, demethoxy curcumin and bis-demethoxy curcumin (Figure 3). The major and most bioactive constituent of $C$. longa rhizome is curcuminoids possessing various pharmacological activities $^{6-13}$ like antioxidant, antiprotozoal, anti-inflammatory, hepatoprotective, antimicrobial, wound healing, anticancer, antitumor, antiviral and anti HIV. In Ayurveda, turmeric has been used internally as a stomachic, tonic, blood purifier and externally in the prevention and treatment of skin diseases ${ }^{14}$. The classical formulations of rhizomes of C. longa is Devadarvarishta, Pippalyadasava, Eladya Modaka, Brahma Rasayana, Haridra Khanda, Punarnavadi Kvatha Churna, Brihanmanjishthadi Kvatha Churna, Rasnadi Kvatha Churna, Saptavimshatika Guggulu, Kasisadi Ghrita, Jatyadi Ghrita, Triphala Ghrita, Maha Kalyanaka Ghrita, Mahapanchagavya Ghrita, Nimbadi Churna, Rajanyadi Churna, Sudarshana Churna, Arimedadi Taila, Kumkumadi Taila, Chandanadi Taila, Chandanabalalakshadi Taila, Jatyadi Taila, Maha Narayana Taila, Lakshadi Taila, Somaraji Taila, Dashanga Lepa, Pathyadi Lepa, Rasnadi Churna, Rasottamadi Lepa Churna, Khadiradi Gutika (Mukha Roga), Chandraprabha Vati, Panchanimba Churna, Brihanmarichadya Taila, Marichadya Taila, Mahalakshadi Taila, Jalodarari Rasa, Yakritplihari Lauha ${ }^{15-16}$. At present, it has attracted interest because of its 
various uses throughout the industrialized and developing world as home remedies and ingredients for the pharmaceutical products. The lack of rapid identification and control of adulterations for rhizome is still being problem. C. longa rhizomes were studied and described along with their physicochemical parameters and HPTLC fingerprint analysis. These parameters will be useful in authentification of rhizomes and identifying the adulterants for quality control of the drug.

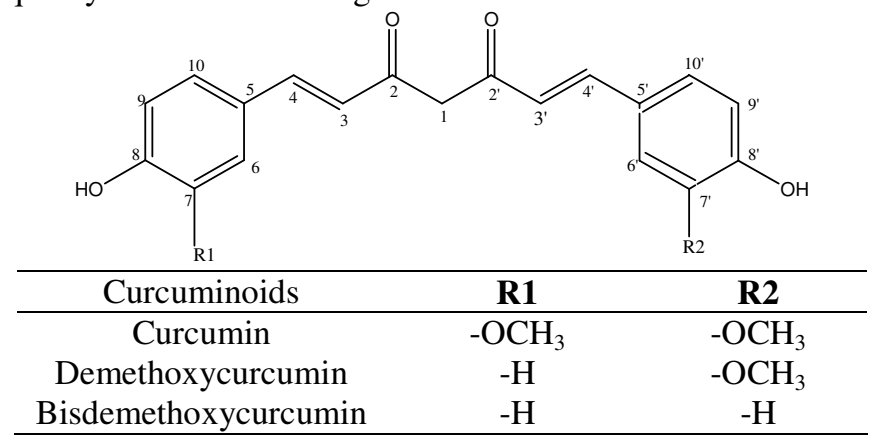

Figure 3. Structure of curcuminoids

\section{Experimental}

All chemicals used were of AR grade and were purchased from Sisco Research Laboratories (Mumbai, India). Curcuminoid purity more than 95\% was used for the analysis. Rhizome of Curcuma longa were purchased from local market of New Delhi, India and identified by the matching of TLC fingerprints with reference standards of Curcuma longa L. rhizome (NISCAIR/RHMD/Consult/2010-2011/1632/230).

\section{Standard preparation}

Standard stock solution containing $1 \mathrm{~g} \mathrm{~mL}^{-1}$ of curcuminoid was prepared by dissolving $10 \mathrm{mg}$ of curcumin in $10 \mathrm{~mL}$ of ethanol. The stock solution was further diluted to attain final concentration of $25 \mu \mathrm{g} \mathrm{mL}^{-1}$ for HPTLC analysis.

\section{Sample preparation}

Dried and powdered rhizomes $(1 \mathrm{~g}$ each) were kept in six different flasks and every flask was extracted separately at room temperature with $15 \mathrm{~mL}$ of solvents mentioned in Table 1 for $18 \mathrm{~h}$. Each extracts were filtered separately. Solvents were removed under vacuum in a rotatory evaporator at $50{ }^{\circ} \mathrm{C}$ and lypholized till each extract was free from solvents. The dried extracts were weighed accurately and percentage yield was calculated as evident in Table 1 .

Table 1. Solvent polarity based extraction of $C$. longa rhizome powder

\begin{tabular}{clccc}
\hline S.No. & $\begin{array}{c}\text { Solvents for } \\
\text { Extraction }\end{array}$ & $\begin{array}{c}\text { Weight of powdered } \\
\text { rhizome, } \mathrm{g}\end{array}$ & $\begin{array}{c}\text { Weight of } \\
\text { Extract, g }\end{array}$ & \% yield \\
\hline 1 & $n$-hexane & 1.014 & 0.0160 & 1.58 \\
2 & Dichloromethane & 1.015 & 0.0179 & 1.76 \\
3 & Ethyl acetate & 1.011 & 0.0191 & 1.89 \\
4 & Acetone & 1.017 & 0.0371 & 3.65 \\
5 & Absolute & 1.016 & 0.0329 & 3.24 \\
& Ethanol & 1.014 & 0.1542 & 15.21 \\
6 & Commercial & & & \\
\hline
\end{tabular}


Each dried extract $(10 \mathrm{mg})$ of $C$. longa rhizome was dissolved separately, in $10 \mathrm{~mL}$ of each solvent i.e. $n$-hexane, dichloromethane, ethyl acetate, acetone, absolute ethanol and commercial alcohol (80\%), respectively to get the sample solution of $1000 \mu \mathrm{g} \mathrm{mL}^{-1}, 4 \mathrm{~mL}$ of each stock sample solution was taken in a $100 \mathrm{~mL}$ volumetric flask separately and added each corresponding solvent in to each flask up to mark, to get the concentration of each sample solution is $40 \mu \mathrm{g} \mathrm{mL}^{-1}$. Each sample solutions were filtered through $0.45 \mu \mathrm{m}$ membrane filters and $5 \mu \mathrm{L}$ of each sample was applied separately to TLC plate for the development of fingerprints.

\section{Chromatography}

Chromatography was performed on $20 \mathrm{~cm} \times 10 \mathrm{~cm}$ TLC plates precoated with $0.25 \mu \mathrm{m}$ layers of silica gel $60 \mathrm{~F}_{254}$ (E. Merck, Germany). Samples were applied to the plates as bands $10 \mathrm{~mm}$ wide by use of a Linomat IV applicator CAMAG (Switzerland) fitted with a $100 \mu \mathrm{L}$ syringe (Hamilton, Switzerland). The application positions $X$ and $Y$ were $10 \mathrm{~mm}$ and $10 \mathrm{~mm}$, respectively, to avoid edge effects. Linear ascending development to a distance of $80 \mathrm{~mm}$ with Chloroform: Methanol: Acetic acid; 9.5: 0.5: 0.1, (v/v/v) as mobile phase was performed in a twin-trough glass chamber $(20 \mathrm{~cm} \times 10 \mathrm{~cm})$ previously saturated with mobile phase vapour for $20 \mathrm{~min}$. The plates were dried in air and photo documented at $\lambda 254 \mathrm{~nm}$ (Figure 4) and $\lambda 366 \mathrm{~nm}$ (Figure 5) using CAMAG Reprostar and WinCATs software (V 1.4.2; CAMAG).

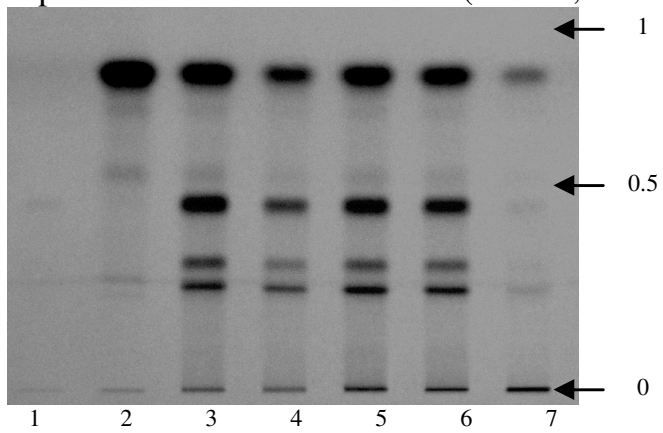

Figure 4. HPTLC fingerprint of extracts of $C$. longa rhizome and standard curcuminoids at $\lambda 254 \mathrm{~nm}$ (1=n-Hexane extract; 2= Dichloromethane extract; 3=Ethylacetate extract; $4=$ Acetone extract; $5=$ Ethanol extract; $6=$ Commercial alcohol extract and $7=$ Curcumanoid)

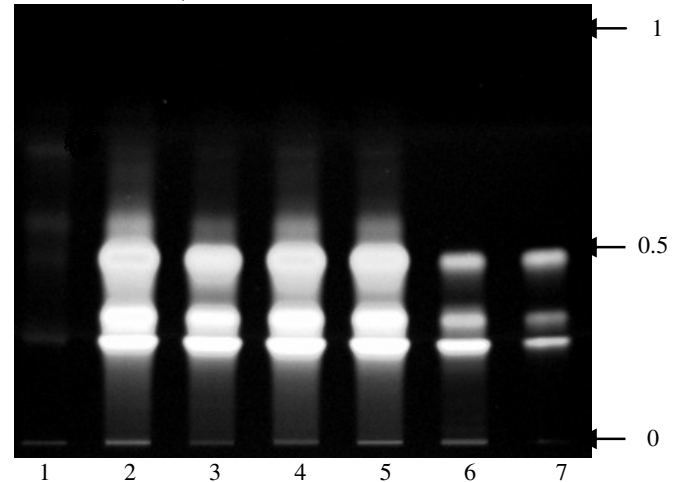

Figure 5. HPTLC fingerprint of extracts of $C$. longa rhizome and standard curcuminoid at $\lambda 366 \mathrm{~nm}$ (1=n-Hexane extract; $2=$ Dichloromethane extract; $3=$ Ethylacetate extract; $4=$ Acetone extract; $5=$ Ethanol extract; $6=$ Commercial alcohol extract and $7=$ Curcumanoid) 


\section{Determination of physicochemical parameters of $C$. longa rhizomes Moisture content}

$4 \mathrm{~g}$ of Dried and powdered rhizomes were taken in a pre-weight $50 \mathrm{~mL}$ beaker and kept in an oven at $105{ }^{\circ} \mathrm{C}$ for $5 \mathrm{~h}$. Removed beaker for oven and kept in a desiccators to cool at room temperature and weighed. Repeat the procedure till constant weight is obtained. Calculate the percentage of loss in weight of the sample ${ }^{17}$.

\section{Total ash}

$2 \mathrm{~g}$ of the sample was taken accurately in a previously ignited and tarred Silica dish. Spread the material evenly and ignite in a muffle furnace by gradually increasing the temperature to $600{ }^{\circ} \mathrm{C}$ until it is white, indicating the absence of carbon. Cool the dish in desiccators and weigh. If carbon free ash cannot be obtained in this manner, cool the dish and moisten the residue with about $2 \mathrm{~mL}$ of water or a saturated solution of Ammonium nitrate. Dry on a waterbath and then ignite in the muffle furnace to constant weight. Cool the dish in desiccators further 30 minutes and then weigh. Calculate the percentage of total ash of air dried material ${ }^{17}$.

\section{Acid insoluble ash}

To the dish containing the total ash, add $25 \mathrm{~mL}$ of hydrochloric acid : water $(1: 5, \mathrm{v} / \mathrm{v})$, cover with a watch glass and boil gently for 5 minutes. Rinse the watch glass with $5 \mathrm{~mL}$ of hot water and add the washings to the dish. Collect the insoluble matter on an ash less filter paper (Whatmann No. 41) and wash with hot water until the residue is free from acid. Transfer the filter paper containing the insoluble matter to the original dish, dry and ignite to constant weight. Cool the dish in desiccators for 30 minutes and then weigh. Calculate the percentage of acid insoluble ash of the air-dried material ${ }^{17}$.

\section{Water-soluble extractive}

$4 \mathrm{~g}$ of the sample was taken in a glass stoppered flask. Add $100 \mathrm{~mL}$ of distilled water, with shake occasionally for 6 hours and then allow standing for 18 hours. Filter the solution and pipette out $25 \mathrm{~mL}$ of the filtrate in a pre-weighed $100 \mathrm{~mL}$ beaker and evaporate to dryness on a water bath. Keep it in an air oven at $105^{\circ} \mathrm{C}$ for 6 hours, cool in desiccators for 30 minutes and weigh. Repeat the experiment twice and take the average value ${ }^{17}$.

\section{Alcohol-soluble extractive}

$4 \mathrm{~g}$ of the sample was taken in a glass stoppered flask. Add $100 \mathrm{~mL}$ of distilled alcohol shake occasionally for 6 hours and then allow standing for 18 hours. Filter the solution and pipette out $25 \mathrm{~mL}$ of the filtrate in a pre-weighed $100 \mathrm{~mL}$ beaker and evaporate to dryness on a water bath. Keep it in an air oven at $105{ }^{\circ} \mathrm{C}$ for 6 hours, cool in desiccators for 30 minutes and weigh. Calculate the percentage of alcohol extractable matter of the sample. Repeat the experiment twice and take the average value ${ }^{17}$.

\section{Results and Discussion}

Polarity based extraction of $C$. longa rhizome powder was done by using different solvent of increasing polarities like $n$-hexane, dichloromethane (DCM), ethyl acetate, acetone, absolute ethanol and commercial ethanol $(80 \%)$. $n$-Hexane is the non polar, dichloromethane and ethyl acetate are the medium polar while acetone, ethanol and commercial alcohol are the most polar solvents were used in extraction of curcuminoids. The percent yield of extracts was found minimum with non polar solvents and maximum with most polar solvents. $n$-Hexane solvent showed lowest yield of extract $(1.58 \%)$ while commercial alcohol showed highest yield of extract (15.21\%), as shown in Table 1. 
Thin Layer Chromatography of $C$. longa extracts was performed on silica gel $60 \mathrm{~F}_{254}$ TLC plate using Chloroform : Methanol : Acetic acid; $9.5: 0.5: 0.1,(\mathrm{v} / \mathrm{v} / \mathrm{v})$ as a mobile phase. These conditions gave maximum resolution of spots. Each extract of $C$. longa showed all spot in grey color at wavelength ( $\lambda$ ) $254 \mathrm{~nm}$ (Figure 4). $n$ - Hexane extract showed no spot while DCM extract showed one spot and other extracts showed four major spot at $\lambda 254 \mathrm{~nm}$ (Table 2). Further, at $\lambda$ $366 \mathrm{~nm}$ (Figure 5) $n$-hexane extract showed no spot while DCM, ethyl acetate, acetone, absolute ethanol and commercial ethanol showed major three spot at $R_{f} 0.26,0.32$ (fluorescent) 0.48 yellow fluorescent, respectively. The $R_{f}$ value of standard curcuminoid sample was matched with $R_{f}$ values of DCM, ethyl acetate, acetone, absolute ethanol and commercial ethanol extracts as evident in Table 2 and Figure 5. These results indicated that ethyl acetate and acetone were the suitable solvent for maximum extraction of curcuminoids form $C$. longa rhizomes because curcuminoidal portion found in high quality as evident in Figure 5.

Table 2. $R_{f}$ value of each spot present in solvent polarity extracts of $C$. longa $\mathrm{L}$

\begin{tabular}{|c|c|c|c|c|c|c|}
\hline $\begin{array}{c}\text { Extract } n \text {-Hexane } \\
1 \\
\end{array}$ & $\begin{array}{c}\text { Dichloro- } \\
\text { methane } \\
2 \\
\end{array}$ & $\begin{array}{c}\text { Ethylacetate } \\
3 \\
\end{array}$ & $\begin{array}{c}\text { Acetone } \\
4\end{array}$ & $\begin{array}{c}\text { Ethanol } \\
5\end{array}$ & $\begin{array}{c}\text { Commercial } \\
\text { alcohol } \\
6 \\
\end{array}$ & $\begin{array}{c}\text { Curcumanoid } \\
7 \\
\end{array}$ \\
\hline $\begin{array}{cc}R_{f} \text { at } & \text { No major } \\
254 \mathrm{~nm} \quad \text { spot }\end{array}$ & $\begin{array}{c}0.26,0.32 \\
0.48,0.56 \\
0.81 \\
\text { (all grey) }\end{array}$ & $\begin{array}{c}0.26,0.32 \\
0.48,0.81 \\
\text { (all grey) }\end{array}$ & $\begin{array}{c}0.26,0.32, \\
0.48,0.56, \\
0.81 \\
\text { (all grey) }\end{array}$ & $\begin{array}{c}0.26,0.32, \\
0.48,0.56, \\
0.81 \\
\text { (all grey) }\end{array}$ & $\begin{array}{c}0.26,0.81 \\
\text { (all grey) }\end{array}$ & $\begin{array}{c}0.32,0.48, \\
\text { (all grey) }\end{array}$ \\
\hline $\begin{array}{c}R_{f} \text { at No major } \\
366 \mathrm{~nm} \quad \text { spot }\end{array}$ & $\begin{array}{c}0.26,0.32 \\
\text { fluorescent } \\
0.48, \text { yellow } \\
\text { fluorescent }\end{array}$ & $\begin{array}{c}0.26,0.32 \\
\text { fluorescent } \\
0.48, \text { yellow } \\
\text { fluorescent }\end{array}$ & $\begin{array}{c}0.26,0.32 \\
\text { fluorescent } \\
0.48, \\
\text { yellow } \\
\text { fluorescent }\end{array}$ & $\begin{array}{c}0.26,0.32 \\
\text { fluorescent } \\
0.48, \\
\text { yellow } \\
\text { fluorescent }\end{array}$ & $\begin{array}{c}0.26,0.32 \\
\text { fluorescent } \\
0.48, \\
\text { fluorescent }\end{array}$ & $\begin{array}{c}0.26,0.32 \\
\text { fluorescent } \\
0.48, \\
\text { fluorescent }\end{array}$ \\
\hline
\end{tabular}

Table 3. Physicochemical parameters of Curcuma longa (rhizome)

\begin{tabular}{clcc}
\hline S.No. & \multicolumn{1}{c}{ Parameters } & Analysis & Remark \\
1. & Foreign matter & Nil & NMT 2.0\% \\
2. & Total ash & $4.5 \%$ & NMT 9\% \\
3. & Acid insoluble ash & $0.86 \%$ & NMT 1\% \\
4. & Alcohol soluble extractive value & $9.42 \%$ & NLT 8\% \\
5. & Water soluble extractive value & $18.26 \%$ & NLT 12\% \\
6. & Volatile oil content & $4.1 \%$ & NLT 4\% \\
\hline
\end{tabular}

The rhizomes of $C$. longa $\mathrm{L}$. were physicochemically standardized in term of determination of extractive value and ash value. Powder of rhizomes showed $4.5 \%$ total ash, $0.86 \%$ acid-insoluble ash content which is found under the limit as mentioned by Ayurvedic Pharmacopoeia of India (API). This indicated negligible amount of foreign matter and less amount of siliceous matter was present in the rhizome of plant. Alcohol soluble extractive was found $9.42 \%$ indicated the presence of polar constituents and non-polar secondary metabolites present in the plant while water-soluble extractive was found $18.26 \%$ indicated the presence of sugar, acids and inorganic compounds. The percentage of total ash, acid-insoluble ash, alcohol-soluble extractive and water soluble extractive were found under the permissible limit of API ${ }^{16}$. Volatile oil content present in the rhizome of the plant was $4.1 \%$. The results are depicted in Table 3. 


\section{Conclusion}

Cost-effective, simple and rapid identification method for authentication of $C$. longa rhizome was developed. Moreover, ethyl acetate and acetone is proposed as most favorable solvent for maximum extraction of curcuminoids from C. longa. If curcumin is targeted for extraction, then dichloromethane is the best solvent for extraction. Quality standards for $C$. longa rhizome were developed using physicochemical and HPTLC fingerprint analysis methods which will be useful in identification and control of adulterations and further studies. The sample preparation and method developed for TLC fingerprinting is very simple and rapid than reported methods. Therefore, we suggested that proposed method can be helpful for routine quality assessment of curcuminoids of $C$. long $a$ and its formulations and food samples.

\section{Acknowledgement}

The authors are grateful to Director General, CCRAS, New Delhi and Principle, M.M.H. College, Ghaziabad for providing necessary facilities. The authors are highly thankful to Ms. Sukriti Nigam, Senior Research Fellow, CCRAS, New, Delhi for assistance.

\section{References}

1. Sharma P C, Yelne M B and Dennis T J, Database of Medicinal Plants used in Ayurveda; Central Council for Research in Ayurveda and Siddha publisher: New Delhi, 2000, Vol-I, 192-199.

2. $\quad$ Shu J H, Flora of China, 2000, 24, 359-362.

3. Anonymous, The Ayurvedic Pharmacopoeia of India; Ministry of Health \& Family Welfare, Govt. of India, The controller of publication, Civil lines: New Delhi, 1989; Part - I, Vol-I, p.45-46.

4. Jayaprakasha G K and Rao L I M and Sakariah K K, Trends food Sci Tech., 2005, 16(12), 533-548.

5. Gupta A P, Gupta M M and Kumar S, J Liq Chromatogr Rel Tech., 1999, 22(10), 1561-1569.

6. Sharma O P, Biochem Pharmacol., 1976, 25, 1811-1812.

7. Ammon H P and Wahl M A, Planta Medica, 1991, 57(1), 1-7.

8. Conney A H, Lou Y R, Xie JG, Osawa T, Newmark H L, Liu Y, Chang R L and Huang M T, Proceedings of the society for Exp. Biol Med., 1997, 216, 234-245.

9. Surh Y J, Nature Rev Cancer, 2003, 3, 768-780.

10. Payton F, Sandusky P and Alworth W L, J Nat Prod., 2007, 70, 143-146.

11. Ruby A J, Kuttan G, Babu K D, Rajasekharan K N and Kuttan R, Cancer lett., 1995, 94(1), 79-83.

12. Belakavadi M and Salimath B P, Mol Cell Biochem., 2005, 273(1-2), 57-67.

13. Sui Z, Salto R, Li J, Craik C, Oritz D and Montellano P R, Bioorg Medicinal Chem., 1993, 1, 415-422.

14. Anonymous, The Wealth of India, A dictionary of Indian raw materials and industrial products, first supplement series (Vol. II); National Institute of Science Communication, CSIR: New Delhi, 2001, 264-293.

15. Anonymous, The Ayurvedic Formulary of India, Part-I, $2^{\text {nd }}$ revised Ed., Ministry of Health and Family Welfare, Govt. of India, The controller of publication, Civil lines: New Delhi, 2003.

16. Anonymous, The Ayurvedic Formulary of India, Part-II, I ${ }^{\text {st }}$ Ed.; Ministry of Health and Family Govt. of India, The controller of publication, Civil lines: New Delhi, 2000.

17. Anonymous, Quality Control Methods for Medicinal Plant materials, WHO, Geneva, 1998, 28-33. 